\title{
Cognitive Constructive - Chronometric Techniques as a Tool for the E-Assessment of Learning
}

\author{
Guadalupe Elizabeth Morales-Martinez
}

Cognitive Science Laboratory, Institute of Research on the University and Education, National Autonomous University of Mexico (UNAM, IISUE), Mexico

\section{Ernesto Octavio Lopez-Ramirez}

Cognitive Science Laboratory, Department of Psychology, Nuevo Leon Autonomous University (UANL), Mexico

\section{Jocelyn Pamela Garcia-Duran}

Cognitive Science Laboratory, Institute of Research on the University and Education, National Autonomous University of Mexico (UNAM, IISUE), Mexico

\section{Maria Elena Urdiales-Ibarra}

Cognitive Science Laboratory, Department of Psychology, Nuevo Leon Autonomous University (UANL), Mexico

\begin{abstract}
The 21st century brought new demands to formal education. For instance, the introduction of information and communication technology (ICT) has revolutionized the conception and the realization of teaching (e.g., online education). Concurrently, in the field of evaluation of learning, advances have been characterized only by the digital encapsulation (digital domestication) of summative and formative assessment instruments, rather than by the generation of native approaches of the digital age. This clearly imposes a current demand to innovate methods and instruments of assessment that are better aligned with the new educational reality, framed by the era of innovative ICT. In particular, e-assessment will benefit by considering current cognitive science and computer science advances in ways that were not possible before. This is the case with the cognitive constructive chronometrical assessment of learning described in this paper. This approach favors innovating formative evaluation, but can be considered as complementary to several endeavors of old masters of educative evaluation.
\end{abstract}

Keywords: E-assessment; learning; ICTs; innovation; cognitive science. 


\section{Introduction}

In recent decades, online learning has had a remarkable development. For instance, at the beginning of the 21st century, some 54,000 online courses were on offer, with around 1.6 million officially enrolled virtual students (Carnevale, 2000).

Even though it is still early to know how online learning will affect educative endeavors, it is clear that benefits are obtained whenever this Information and Communication Technology (ICT) digital learning option is appropriately applied to educational settings.

Along with this education technology development, there is a need for conceptualization of pre-established educational concepts into virtual education environments. This is the case for re-conceptualizing e-assessment of learning, its goals, and ways of implementation to be in accordance with the new ways of e-instruction (García, 2011; Gordon \& Rajagopalan, 2016). However, even when there is an implicit academic consensus on the need to renew ways to asses online learning to match functionality and other demands of virtual classrooms, there is still no general systematic agreement on how to achieve this goal to align with the idea of a 21st century virtual classroom. In fact, this need for a change is inherent to assessment, since this concept has evolved from being a tool for prediction and control toward an instrument for comprehending what a student knows, to visualize meaning of what is learned (Berry \& Adamson, 2011) and, as it has been recently proposed, to consider assessment as a path to transformation (Shute \& Becker, 2010).

Here, we will briefly describe some assumptions concerning the evaluation of students' knowledge through modern time. Furthermore, it will be discussed how the transition among stages occurred due to theoretical and applied development needs framed by new ways of thinking (contextual factors), emerging educational technology resulting from theoretical and methodological advances on curriculum design and understanding of human learning (situational factors), as well as intrinsic aspects of academic performance assessment (evaluation goals, consideration of the problems being evaluated, and performance variables to measure) (Corrigan, Buntting, Jones, \& Gunstone, 2013; Stufflebeam, Madaus, \& Kellaghan, 2002).

Let us first consider the impact that the industrial revolution thinking has had on the concept of people's productivity and how this view was incorporated into educational settings. In the 17th century, chemist William Farish, inspired by quantifying productivity, proposed a new grading system that consisted of imposing quantitative grading for testing academic performance (Stufflebeam et al., 2002). This proposal was permeated by a positivist thinking framed by the context of available technology, as well as by a curriculum resting on quantitative indicators of productivity.

Even though the need to measure a person's competencies and/or knowledge was not an exclusive concept of Farish's era, as personal selection in the ancient 
China was, for example, based on quantitative indicators to measure academic performance (Gordon \& Rajagopalan, 2016), his approach to performance quantification within the education field was considered innovative because this allowed for the first time for students' academic performance to be given a numerical connotation that leads to systematicity and standardization of learning evaluation (e.g., reliability and validity) (Chiappelli, 2014). It also permitted the consideration and inclusion of psychometric factors to frame academic performance, and highlighted the need to implement efficient administrative procedures considering academic performance indicators, as promoted by Frederic Taylor in the early 1930s. Still, developing a monitoring process to acknowledge curriculum goal achievement was the most important (Stufflebeam \& Shinkfield, 1989).

Nevertheless, around the 1970s, this systematic approach to evaluation of learning had the barest of welcomes by the new emerging human learning theories. By then, it was required that assessment of learning serve as a means for learner transformation/change and a support for the learning process. It was this new view that led to the concept of formative assessment. Later, a new need to develop evaluation tasks closer to real-life problems and challenges that students face outside their education institutions led to the development of "authentic assessment of learning." In the 1980s, the need to empower student performance through assessment of learning led to the idea that students should modulate their own learning assessment, which in turn led to the concept of selfassessment and evaluation by pairs. Following from these innovations to assessment of learning, in the early 1990s, an emphasis was given on evaluating students' learning processes (Boud, 2007). Generally speaking, these changes in perspective lead to a transition path that considers assessment of learning as being a tool that goes from monitoring learning (evaluation of learning), as a feedback instrument (evaluation as learning) and as a path to transformation (evaluation to learn) (Corrigan et al., 2013).

Nowadays, instruction and teaching-framed by innovative educational technology that includes original uses of multimedia, virtual-learning platforms, tools to socialize knowledge, etc.-empower students with no previously identified teaching and learning options. From a historical perspective, the inclusion of these ICTs into education would represent another revolution where students' and teachers' minds are re-conceptualized within digital contexts. Furthermore, the advent of new ICT within educative settings urges us again to reconsider and transform our precepts regarding assessment of learning, leading many of our empirical and applied research lines into a new era. This does not imply only digital domestication of previously established methods of evaluating knowledge acquisition (like repeating, test measurement, or performance evaluation by digital means), but also innovating educational technology by designing truly digital native e-assessment methods.

On the other hand, blending e-assessment into a historical trend line does not just imply ignoring previous methods for evaluating students' academic performance and beginning from zero. As we will argue next, by considering 
empowerment of previously established cognitive science research methods on human learning with recent computer science advances, innovative ways to evaluate distance learning, and especially online learning, will emerge. Then, pointing to a context emphasizing the need to innovate assessment methods that lead us to consider technology-empowered cognitive science resources to be included as a way to innovate e-assessment. In order to introduce this argumentation, let us first consider some current challenges regarding assessment of learning.

\section{Some current challenges and scope to evaluate learning.}

The concept of evaluation within the context of knowledge acquisition has a wide variety of connotations (Corrigan et al., 2013). For instance, this concept is traditionally described as a monitoring the learning process (Fitzgerald \& Gunstone, 2013), as a way to identify weaknesses and strengths (Tillema, 2009), or as a collection of academic indices and systematic analysis methods aimed at students' comprehension of course contents and/or achievement of academic goals (Shute \& Becker, 2010).

Currently, assessment of learning has to comply with the Joint Committee on Standards for Educational Evaluation requirements. That is, evaluation has to be useful, feasible, ethical, and exact (Stufflebeam et al., 2002). Regarding usability, current evaluation programs tend to be guided by local, national, or international educative institutions' needs. For instance, if the goal is to follow students' academic performance, then evaluation can be used as a diagnostic tool to indicate the exact starting point of academic performance (Joughin, 2009). Conversely, if the formative aspect is under scrutiny, then the "process" underlying students' knowledge acquisition becomes the main focus of interest (Bell \& Bronwen, 2002; Sanders \& Horn, 1995). On the other hand, if only the outcome of students' academic performance needs to be evaluated, a "summative" approach is considered (Muldoon \& Lee, 2007). This is currently the dominant approach and is characterized by the use of standardized metric indices of academic performance (Gipps, 1994; Madaus \& Stufflebeam, 2002). Furthermore, as we will describe later, evaluation of learning can be enriched by alternative cognitive science approaches to evaluation, such as the one presented by Morales and Lopez (2016) as well as Seel (2010), entitled cognitive constructive/responsive assessment of learning.

The concept of precise evaluation (reliability and validity) is central to all academic approaches considering it to offer an instrument that really measures what instruction intends to teach (Black \& Wiliam, 1998). In this way, teaching and assessment of learning seem to be intrinsically linked and/or mutually defining (Frankland, 2007). From here, it is derived that evaluation of academic performance (e.g., grading) must be timely (to comply with curriculum goal schedule) and in suitable form (framed by a pedagogical or andragogic model) to satisfy modern requirements of an educative institution and society. Concerning this point, it is debatable if indeed these last requirements on evaluation are accomplished. For instance, it is argued that current standardized 
testing does not measure what students have learned in a course (Marzano, 1994; Marzano \& Costa, 1998) but rather what they did not learn (Ifenthaler, Dummer \& Seel, 2010). Moreover, it is argued that there are not too many congruencies between what is taught and what is evaluated by current educative institutions.

As a matter of illustration, let us consider the concept of client-centered evaluation (Stufflebeam \& Shinkfield, 1989). Here, evaluation serves a client (educative institution / corporation) by providing indices of success. A student is considered the consumer of what these clients offer. However, frequently, client interests do not necessarily match consumer needs and expectations. An example of this incongruence can be found in the constructivist approach and its varieties, like the constructionism model, the critical and cultural constructivism, etc. (Dougiamas, 1998; Payne, 2009). Evaluation of learning under these approaches is mainly based on students' satisfaction indices (Ebrahimi, 2015; Eom, Wen, \& Ashill, 2006) rather than serving as an indicator of a process of knowledge construction (currently, there is no instrument to evaluate truly constructivist postulates). The question is thus if satisfaction indices and valuation of achievement goals describe what students learn. Students' higher satisfaction does not necessarily equate to better learning outcomes (consumer needs). Furthermore, notice that most of these learning indices were in use before the constructivist model arrived into educative settings.

Overcoming discrepancies between what and how knowledge is taught and how it is evaluated is not only a challenge to the constructivist model but for most online and on-site teaching and learning models. This challenges regarding assessment of learning are now more constrained by the advent of a 21st century digital classroom. This imposes a demand for not only modifying our precepts of a client or a consumer of formal education, but requires us to produce innovative education technology that is incorporated into a historical trend line, likely resulting in many benefits but also limitations, challenges, and problems. In doing so, the hope is to reduce limitations to enhance benefits and, as will be discussed next, the possibility of seeing new empirical research directions to solve assessment of learning problems.

\section{A need for innovating assessment of learning within the 21st century educative digital era.}

Several decades ago, the digital culture has started permeating academic endeavors of teaching and learning inside educative institutions. A robust infusion of TICs into education has been typified since the 1960s with the first computer-assisted instruction systems (PLATO, TICCIT, etc.) combined with computer expert systems or intelligent guided instruction, such as Intelligent Computer Assisted Instruction (ICAI) (Sternberg, 1985), leading to the more recent virtual learning platforms like Learning Space, Moodle, Blackboard, aimed at enhancing and facilitating collaborative and cooperative learning. These digital tools have empowered students and teachers with accessibility to an incredibly fast-changing world of knowledge through digital basis and 
semantic web (Devedzic, 2006) and augmented reality or augmented education (Klopfer, 2008) even before this knowledge is printed and distributed by standard methods.

However, by comparing the e-instruction development with the development of evaluation of online learning, we cannot help but notice a significant delay regarding e-assessment innovation. As a result, the concept of learning evaluation has been reduced to digital encapsulation of previously established evaluation methods. Let us expand on this concept on digital encapsulation.

In general, in distance learning (which includes online education), three approaches are employed to evaluate student learning, namely testing and grading to assess students' academic achievements, scales to check for students' attitudes to distance learning, and students' satisfaction indices toward distance learning (The Institute for Higher-Education Policy [TIHEP], 1999). These three broad approaches and the corresponding measurement tools that can be applied to evaluate distance learning constitute an inheritance from previously established on-site/face-to-face evaluation methods, such as testing (Gallego, Quesada, \& Cubero, 2011; Horton, 2001, Khan, 2005; TIHEP, 1999); essays and research projects (Gallego et al., 2011); diaries, anecdotic records, and field notes (Gallego et al., 2011); and interviews (Psaromiligkos, Spyridakos, \& Retalis, 2014). Accordingly, the strengths and weaknesses of these learning evaluation approaches were inherited by distance learning, and e-assessment of learning in particular.

However, inclusion of weaknesses and strengths of an assessment approach into e-assessment does not imply finding a way to encapsulate/incorporate its postulates by digital means as a solution that is, by digitally framing its historical trend line. Rather, in order to innovate a highly technologized 21st century e-assessment, a selected established trend line on evaluation can transform itself by blending and assimilating itself with computer science innovation permeated by recent advances in understanding human learning. In addition, this should be achieved in a way that was impossible by standard assessment methods. Some academic efforts responding to this demand are briefly examined next. Here, it is sufficient to say that at least four important aspects have to be recognized:

1. Evaluation of what a student learns or assimilates must recognize prior knowledge schemata (Assessment Reform Group [ARG], 1999).

2. Empower a teacher with information of what a student learns and how she/he constructs knowledge (constructivist approach) in order to facilitate a student transformation based on learning (ARG, 2002).

3. A capacity to embed digital educational technology contexts into innovation and development (I\&D) research regarding e-assessment (Gómez, Rodríguez, \& Ibarra, 2011). 
4. Promoting innovation in education technology as a way to change political regulations pertaining to assessment of learning.

Take as an example the constant argumentation presented by Nelson in the early 1980s against digital domestication of previously established reading and writing methods (e.g., reading a pdf document or writing a document by using a word processor). As an alternative prototype, Nelson (1982) presented his XANADU project the "Docuverse" (the concept of a universal document constructed by parallel contributions of knowledge from a diversity of authors). His ideas led to the construction of the "hypertext" concept and the implementation of a world wide web. Furthermore, Nelson's ideas have promoted reconsideration of international politics and education, as well as all educational efforts on digital domestication. In the future, it is expected that this author's approach will spread across all educative contexts, including the field of online learning evaluation.

Clearly, complying with these requirements is not an easy task, but emerging empirical research lines are providing guidelines for innovation in this field. As an example, let us observe the following cognitive science proposal constrained by the appointed requirements to innovate e-assessment.

\section{Exploring a new world on e-assessment through cognitive science education technology.}

A burst of new reported advances in cognitive science research, cognitive ergonomics, and engineering psychology (Harris, 2007) has shown how many recent cognitive educative approaches can be implemented through education technology to complement students' academic endeavor. Thus, brain-based programs (Jensen, 2008), andragogy teaching and learning methods (Knowles, Holton, \& Swanson, 1998), or learning style approaches (Cordell, 1991) to teaching can be all technology enhanced by digital means (Diethelm \& Mittermeir, 2013; Woolf, Aimeeur, Nkambou, \& Lajoie, 2008). These strategies would allow the development of cognitive-based teaching and learning programs that combine cognitive research methods for studying human learning with recent advances in computer science in ways that have not been previously possible.

In order to explore this frontier, let us first provide a brief description of some current cognitive-oriented teaching and learning programs that frame the idea of education technology innovation.

In the early 1980s, the Midwest educational development laboratory (NCREL) and the Association for Curriculum Development (ASCD), under supervision of Ronald Brandt, organized a meeting attended by experts on cognition and education having in mind an educative reform under a project entitled "Dimensions of thinking." At this meeting, researchers systematically integrated many cognitive science accounts for human learning into educational settings, which resulted in a book entitled Dimensions of thinking and cognitive instruction 
(Jones \& Idol, 1990; Marzano et al., 1988, 1991). In turn, this work was specified to fit curriculum development and the development of educational environments and was called "the dimensions of learning project." The project postulates that a reliable student learning process should go through five stages of learning, namely positive attitude towards learning, acquisition and assimilation of knowledge, knowledge refinement, meaningful use of knowledge, and mental productive habits (Marzano \& Pickering, 1991).

The dimensions of learning project have led to the development of a variety of cognitive teaching and learning methods aimed at developing thinking processes, such as SOI, BASICS, ADAPT, DOORS, COMPAS, DORIS, and SOAR (Campbell, Campbell, \& Dickinson, 1998; Nickerson, 1987; Nickerson, Perkins, \& Smith, 1985); Development of Thinking Abilities Program (De Sánchez, 2004); and Feuerstein's Developmental Enrichment Program (FIE) (Feurstein, 1993).

Two aspects stand out from these seminal initiatives. First, affective processes are considered requirements for learning, choice making, and problem solving. This aligns with the current view that cognitive emotional processing constitutes a guide for students to improve their academic performance (ARG, 2002). Second, some cognitive programs promote acquiring contextualized competencies. This is a relevant aspect that is considered in authentic evaluation and situated cognition learning. For instance, according to Gomez et al. (2011), eassessment is tuned to e-learning as a technology mediated learning process promoting acquisition of competencies that will be useful and valuable in future labor contexts.

The Marzano et al.'s (1992) dimensions of learning model postulates that it is not until a dimension of conceptual organization has appropriately emerged that is possible to develop dimensions regarding meaning and knowledge refinement, and thus to develop learning habits and intellectual abilities.

Congruent with their view, cognitive psychology postulates that human mind organizes incoming information in order to form meaning patterns of events and objects to explain experiences (Lachman, Lachman, \& Butterfield, 1979; Lindsay \& Norman, 1977). Here, learning is conceptualized as an active constructive process-Human Information Processing (HIP) constructive metaphor-to acquire meaning of what is learned. Conceptualizing student learning in this way has lead teaching to implement a variety of cognitive strategies for instruction (Figure 1) that empower students as constructors of their own knowledge (Mayer, 1996) and teachers and educative environments as learning facilitators. However, there is an ongoing debate on how to evaluate this constructivist learning (Nichols \& Sugrue, 1999), since standard evaluation methods of learning (testing, learning activities, satisfaction indices, etc.) are not suitable for testing or validating the HIP learning postulates. As noted previously, they were designed to test what is not learned by a student (Ifenthaler et al., 2010), rather than what is retained in long-term memory (Marzano, 1994; Marzano \& Costa, 1998). 


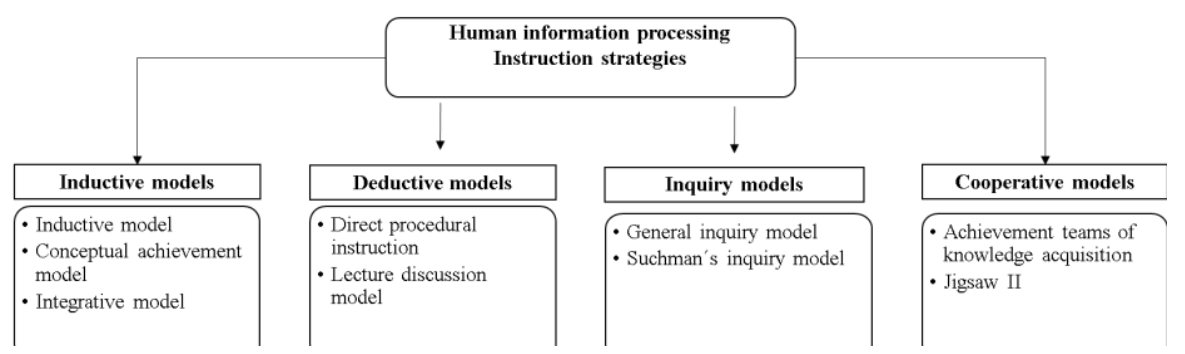

Figure 1. Cognitive approaches to instruction base on human information processing models. Adapted from Strategies for teachers: Teaching content and thinking skills (3rd ed.) by P. D. Eggen, \& D. P. Kauchak, 1996, Boston, MA: Allyn and Bacon.

Difficulties in standard evaluation of learning methods have led to the development of alternative scientifically tested techniques to determine organization, structure, and assimilation of newly acquired knowledge by students in their educational context. Seminal efforts in this direction were typified by the use of a variety of visual tools that allow comparison between an initial state of knowledge and the learning outcome after a course, such as concept maps and semantic nets (Holley \& Dansereau, 1984) and causal diagrams, tree diagrams, bubble maps, etc. (Hyerle, 2009). These were followed by an increasing emphasis on quantifying visual concept organization and systematic qualitative analysis of a course-acquired knowledge shown through these visual tools, e.g., semantic networks (Clariana \& Koul, 2004; Clariana, Koul \& Salehi, 2006; Holley \& Danserau, 1984). It was assumed that, by using these tools, students could externalize, in a consciously controlled way, the knowledge they retained in their long-term memory after a course. This allowed to contrast their concept organization (course schema) with the teacher's/expert's knowledge schema (Itoyama, Nitta, \& Fujiki, 2007; Jonassen, Beissner, \& Yacci, 1993).

This kind of alternative formative way to evaluate knowledge has brought attention to some interesting facts about the way students learn. For instance, longitudinal research has shown that, in the long term, students do not retain testing knowledge in the long-term memory, but rather store a general schema of course contents (Conway, Cohen, \& Stanhope, 1991, 1992). As attractive as it might be to observe what is learned by a student, this approach presents at least two important limitations. First, a study conducted in Germany (Holley \& Danserau, 1984) showed significant evidence revealing student resistance and low adaptation to the use of concept-oriented visual tools as a way to evaluate their learning. Second, a curricular agenda as it is considered currently cannot afford to wait to see what is learned by students in the long run to evaluate students' academic performance.

In order to overcome these important limitations, new research directions are required. Even though some cognitive proposals can be considered, let us focus next on a current cognitive research project responding to this demand. 


\subsection{Chronometric evaluation of schemata footprints: An alternative view of the assessment of learning}

Current cognitive research has suggested that, by using non-artificial semantic nets to show meaning formation (Morales \& Santos, 2015) as well as semantic priming studies, it is possible to determine schemata-related concepts in the human lexicon (Lopez \& Theios, 1996). This is relevant because another limitation to schemata evaluation due to learning can be overcome. Specifically, it has been theoretically argued that no data structures like schema of knowledge exist in long-term memory, but they emerge as required by a person to signify events or objects (Rumelhart, Smolensky, McClelland, \& Hinton, 1986). Still, according to Lopez and Theios (1996), schemata activity and its impact on concept organization in the long term can be specified by tracking temporal activation and processing time of schemata-related concepts in our memory. This is relevant to education because schemata formation (construction) due to learning is the main objective of the HIP constructivist approach to learning evaluation.

If indeed schemata relations can be established among concepts, then semantic priming studies (aimed at chronometrical evaluation of semantic relations among concepts) should detect this type of relations as different from other semantic-related concepts (e.g., associative, categorical, etc.). Accordingly, schemata priming must be obtained in a semantic priming study. That is, one concept should facilitate recognition of another one only if they have a schema relation (Lopez \& Theios, 1992, 1996). If so, a temporal track of schemata acquisition can be assured.

This temporal footprint impingement over our memory capacity to process specific organized information has been used as a tool to implement chronometrical techniques to innovate assessment of student learning. For instance, computerized use of semantic priming studies has allowed us to detect schemata priming after formal school courses (Gonzalez, Lopez, \& Morales, 2013; Morales \& Lopez, 2016). Follow-up studies in this direction have used this chronometrical approach to evaluation in combination with neural network classifiers to discriminate students who stored course contents in long-term memory from those who did not (Gonzalez et al., 2013; Lopez, Morales, Hedlefs, \& Gonzales, 2014; Morales \& Lopez, 2016; Morales, Lopez, \& González, 2015; Morales \& Santos, 2015).

In addition, as it will be discussed next, by combining chronometrical evaluation with mental representation techniques to evaluate knowledge organization due to learning, new approaches to formative evaluation emerge, aimed specifically at empowering online learning environments. 


\subsection{Cognitive constructive - chronometric e-assessment of learning}

Several recently conducted studies (Gonzales et al., 2013; Lopez et al., 2014; Morales \& Santos, 2015; Morales et al., 2015; Morales \& Lopez, 2016) were based on a neural net classifier that uses students' reaction times to recognize schemata-related concepts as a way to classify students' performance as successful or unsuccessful independently from course assessment scores. As shown in Figure 2, the neural net report of students' performance is assembled in a more complex way to evaluate learning, that is, inside a constructivechronometric assessment of learning approach.

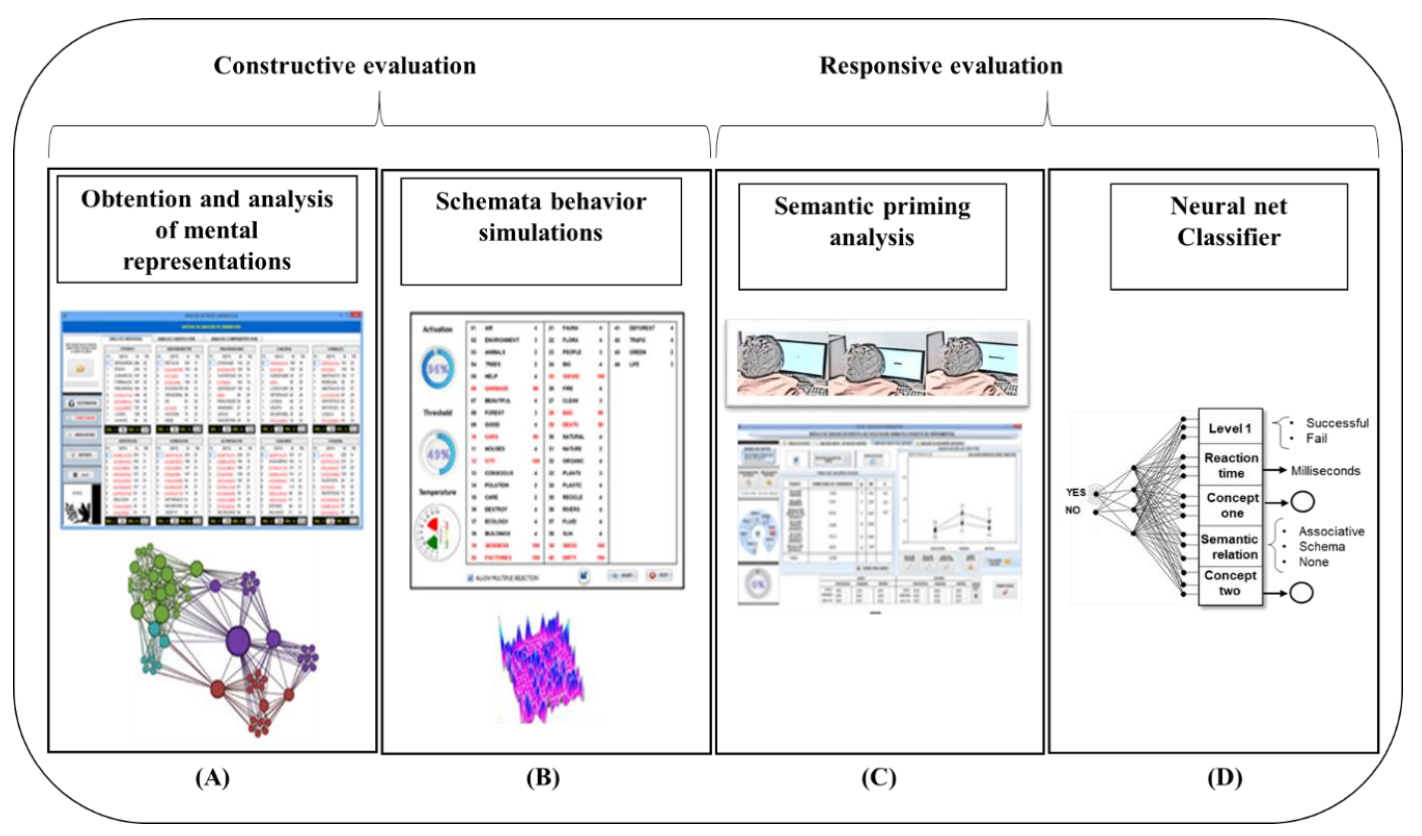

Figure 2. Cognitive constructive - chronometric e-assessment of learning (Called EVCOG). Words related by schemata course content are selected by a constructive evaluation (A-B). These can be used to establish whether a student has fully integrated new information in her/his long-term memory by considering recognition time of these concepts in semantic priming studies (C). These word recognition times allow a trained a neural classifier (D) to distinguish students who integrate long-term information from those who do not.

This kind of assessment models allows overcoming limitations implicit in the initial cognitive constructive models of learning evaluation, and at the same time promotes education technology innovation. For instance, research previously discussed in this article revealed that students rejected the use of concept maps as tools to evaluate their learning (Holley \& Danserau, 1984). On the other hand, it takes long time to determine what is learned by students in the long term, outside of what is permitted by a curricular agenda (Clariana \& Koul, 2004; Clariana, Koul, \& Salehi, 2006; Conway et al., 1991, 1992). However, the assessment model presented in Figure 3 allows immediate assessment of students' retention of acquired knowledge, thus overcoming curricular time agendas. In addition, natural semantic nets, as presented in this approach, are 
used to evaluate the way students impose or create meaning (Figueroa, Gonzales, \& Solis, 1975; Perez, Hernandez, Bustillo, \& Figueroa, 2012) over what is learned. This contrasts with the idea of just comparing concept organization and inclusion of acquired knowledge against an idiosyncratic knowledge concept map. This is possible since, in a natural semantic net, students provide their own conceptual definitions to present target concepts obtained from a teacher. Thus, tracking students' meaning formation during a course becomes the goal of learning assessment.

Semantic priming studies based on this approach use the most relevant concepts related to meaning formation and/or schemata formation by using computerized simulations of emergent course schemata (Rumelhart et al., 1986) which in turn allow the neural net classifier to analyze how students automatically process (not in a controlled or conscious way) course content information. This is excellent, since students cannot cheat on such tests, allowing the teacher to determine if they assimilated the course content in the long-term memory, or merely retained it in short-term memory in order to succeed in the course (e.g. retaining knew knowledge to pass a test).

Notice that, in a cognitive constructive chronometrical assessment of learning like the one described, chronometrical evaluation strongly depends on proper selection of semantic stimuli obtained by constructive evaluation. In turn, determining semantic stimuli relevant to learning assessment depends on how selected concepts facilitate schemata priming detection. This is a mutually dynamic definition task that demands previous research of a knowledge domain before assessment of learning in a course can be considered.

Thus, a constructive chronometrical approach to assessment of learning is compatible with the idea of a teacher and students jointly pursuing learning goals, identifying best paths to achieve such goals by knowing where exactly they stand in the process of acquiring new knowledge (ARG). Finally, empirical research considerations under this approach open the possibility of exploring difficult topics like emergent emotion schemata and the way concept emotions affect knowledge acquisition (Sharon, Tettega, \& Mcreery, 2015), as well as concept organization and intellect development (Izard, 1993). Interestingly, emotion is most relevant to meaning formation (Power \& Dalgleish, 2008) and affective priming studies (Musch \& Klauer, 2003) can be used chronometrically as in semantic priming studies to assess learning.

\section{Conclusions}

In the 21st century education era, mixing tradition and innovation seems to be inevitable. One side of the coin claims to serve the well-established summative assessment of learning (e.g., standardized assessments). Despite various criticisms of the mechanisms and tools based on this learning assessment approach, this system has survived through time. To date, modern summative evaluation has been implemented as a digital domestication of previously 
established assessment methods and tools. Still, the critics claim that the digital encapsulation of evaluation methods does not necessarily mean that there is a renewal or reconceptualization of evaluation of learning.

The other side of the coin shows a different face, where assessment of learning is understood as a tool for learning (in contrast to summative vision) and innovative teaching. The main concern of this approach is that, in order to survive in an era constrained by digital educational technology, it is necessary to adapt and renew typical approaches to evaluation of learning through innovation. The coin is spinning and currently there is no way to predcit which side will prevail or if it will be endlessly rotate.

As this spinning process continues, cognitive science has something to say in this respect. Mainly, advances in the understanding how humans learn and in computer science are remarkable. The application of these advances to the field of educational technology will bring innovative and highly enriched evaluation methods. As previously noted, innovation demands understanding by teachers and students of how their brains learn. Cognitive reports are not summative reports, and these bet on the coin falling to one side representing assessment for learning.

Even though cognitive science reports due to their rigorous scientific origin are prone to quantification, the goal of this metric is to reveal what is learned, rather than what is not learned by students. Clearly, this kind of evaluation can only be useful if it is implemented on digital platforms. More research is thus needed to ascertain how this kind learning assessment will affect e-instruction and what kind of cognitive ergonomic design is needed for digital delivery.

\section{Acknowledgements}

This study was supported by DGAPA-UNAM with a grant from the Support Program of Research and Technological Innovation Projects (PAPIIT) $<<$ TA400116>>.

\section{References}

Assessment Reform Group [ARG] (1999). Assessment for learning: beyond the black box. Cambridge, UK: University of Cambridge. Retrieved from http://www.nuffieldfoundation.org/sites/default/files/files/beyond_blackbox .pdf

Assessment Reform Group [ARG] (2002). 10 principles of assessment for learning. Cambridge, UK: University of Cambridge. Retrieved from http://www.unikoeln.de/hf/konstrukt/didaktik/benotung/assessment_basis.pdf

Bell, B., \& Bronwen, C. (2002). Formative assessment and science education. New York, NY: Science \& Technology Education Library, Kluwer Academic Publisher.

Berry, R., \& Adamson, B. (2011). Assessment reform past, present and future. In R. Berry \& B. Adamson (Eds.), Assessment reform in education: Policy and practice (pp. 3-14). New York, NY: Taylor \& Francis. 
Black, P., \& Wiliam, D. (1998). Assessment and classroom learning. Assessment in Education: principles, policy \& practice, 5(1), 7-73.

Boud, D. (2007). Reaffirming assessment as if learning were important. In D. Boud \& N Falchikov (Eds.), Rethinking assessment in higher education. Learning for the longer term (pp. 14-25). London, UK: Routledge.

Campbell, L., Campbell, B., \& Dickinson, D. (1996). Teaching and learning through multiple intelligences (2nd ed.). London, UK: Allyn \& Bacon.

Carnevale, D. (2000). Survey Finds $72 \%$ Rise in Number of Distance-Education Programs. Chronicle of Higher Education, 46(18), A57. Retrieved from http://www.nyu.edu/classes/jepsen/chronicle010700.html

Chiappelli, F. (2014). Fundamentals of evidence-based health care and translational science. Berlin, Germany: Springer Verlag.

Clariana, R. B., \& Koul, R. (2004). A computer-based approach for translating text into concept map-like representations. In A. J. Cañas, J. D. Novak, \& F. M. González (Eds.), Concept maps: theory, methodology, technology (Vol. 2, pp. 14-17), The Proceedings of the First International Conference on Concept Mapping, Pamplona, Spain, September, 2004. Retrieved from http://cmc.ihmc.us/papers/cmc2004045.pdf

Clariana, R. B., \& Koul, R. (2008). The effects of learner prior knowledge when creating concept maps from a text passage. International Journal of Instructional Media, 35(2), 229-236.

Clariana, R. B., Koul, R., \& Salehi, R. (2006). The criterion-related validity of a computerbased approach for scoring concept maps. International Journal of Instructional Media, 33(3), 317-326. Retrieved from www.personal.psu.edu/rbc

Conway, M. A., Cohen, G., \& Stanhope, N. (1991). On the very long-term retention of knowledge acquired through formal education: Twelve years of cognitive psychology. Journal of Experimental Psychology: General, 120(4), 395-409. doi:10.1037/0096-3445.120.4.395

Conway, M. A., Cohen, G., \& Stanhope, N. (1992). Very long-term memory for knowledge acquired at school and university. Applied Cognitive Psychology, 6(6), 467-482. doi:10.1002/acp.2350060603

Cordell, B. (1991). A study of learning styles and computer-assisted instruction. Computers Educ., 16(2), 175-183.

Corrigan, D., Buntting, C., Jones, A., \& Gunstone, R. (2013). Valuing assessment in science education: An introductory framework. In D. Corrigan, R. Gunstone, \& A. Jones (Eds.), Valuing Assessment in Science Education: Pedagogy, Curriculum, Policy (pp. 1-9). Dordrecht, New York: Springer. doi:10.1007/978-94-007-6668-6

Devedzic, V. (2006). Semantic web and education. Integrated series in information systems (Vol. 12). New York, NY: Springer-Verlag.

Diethelm, I., \& Mittermeir, R. T. (2013). Informatics in schools: sustainable informatics education for pupils of all ages. Proceedings of the 6th International Conference on Informatics in Schools: Situation, Evolution, and Perspectives, ISSEP 2013. Oldenburg, Germany: Springer.

Dougiamas, M. (1998). A journey into constructivism. Retrieved from https://dougiamas.com/archives/a-journey-into-constructivism/

Ebrahimi, N. A. (2015). Validation and application of the Constructivist Learning Environment Survey in English language teacher education classrooms in Iran. Learning Environments Research, 18(1), 69-93. 
Eggen, P. D., \& Kauchak, D. P. (1996). Strategies for teachers: Teaching content and thinking skills (3rd ed.). Boston, MA: Allyn and Bacon.

Eom, S. B., Wen, H. J., \& Ashill, N. (2006). The Determinants of Students' Perceived Learning Outcomes and Satisfaction in University Online Education: An Empirical Investigation. Decision Sciences Journal of Innovative Education, 4(2), 215-235. doi:10.1111/j.1540-4609.2006.00114.x

Feurstein, R. (1993). La teoría de la modificabilidad estructural cognitiva: un modelo de evaluación y entrenamiento de los procesos de la inteligencia. In J. Beltrán (Ed.), Intervención Psicopedagógica (pp. 39-48). Madrid, Spain: Pirámide.

Figueroa, J. G., Gonzales, G. E., \& Solis, V. M. (1975). An approach to the problem of meaning: Semantic networks. Journal of Psycholinguistic Research, 5(2), 107-115.

Fitzgerald, A., \& Gunstone, R. (2013). Embedding assessment within primary school science: A case study. In V. J. Shute. \& B. J. Becker (Eds.), Innovative assessment for the 21st century (pp. 307-324). New York, NY: Springer Verlag.

Frankland, S. (Ed.) (2007). Enhancing teaching and learning through assessment. New York, NY: Springer Verlag.

Gallego, B. N., Quesada, S. V., \& Cubero, I. J. (2011). Medios, técnicas e instrumentos de evaluación. In G. G. Rodríguez \& S. M. S. Ibarra (Eds.), E-Evaluation orientada al eaprendizaje estratégico en educación superior (pp. 95-113). Madrid, Spain: Narcea, S. A. de Ediciones.

García, J. E. (2011). Prologue. In G. G. Rodríguez \& S. M. S. Ibarra (Eds.), E-Evaluation orientada al e-aprendizaje estratégico en educación superior (pp. 13-16). Madrid, Spain: Narcea, S. A. de Ediciones.

Gipps, C. V. (1994). Beyond testing. London, UK: The Falmer Press.

Gómez, R. M. A., Rodríguez, G. G., \& Ibarra, M. S. (2011). Caracterización de la eEvaluación orientada al e-Aprendizaje. In G. G. Rodríguez \& S. M. S. Ibarra (Eds.), E-Evaluation orientada al e-aprendizaje estratégico en educación superior (pp. 33-56). Madrid, Spain: Narcea, S. A. de Ediciones.

Gonzalez, C. J., Lopez, E. O., \& Morales, G. E. (2013). Evaluating moral schemata learning. International Journal of Advances in Psychology, 2(2), 130-136.

Gordon, E. W., \& Rajagopalan, K. (2016). The testing and learning revolution: The future of asssessment in education. Hiundmill, Basingstoke, Hampshire, UK: Palgrave Macmillan.

Harris, D. (2007). Engineering psychology and cognitive ergonomics. 7th International Conference, EPCE Held as a Part of HCI International, Beijing, China, July 2007.

Holley, C. D., \& Dansereau, D. F. (1984). Networking: The technique and the empirical evidence. In C. D. Holley \& D. F. Dansereau (Eds.), Spatial learning strategies: Techniques, applications and related issues (pp. 81-108). New York, NY: Academic Press.

Horton, W. (2001). Evaluating e-learning. Alexandria, VA: American Society for Training \& Development (ASTD).

Hyerle, D. (2009). Visual Tools for Transforming Information into Knowledge (2nd ed.). USA: Corwin press.

Ifenthaler, D., Pirnay-Dummer, P., \& Seel, N. M. (2010). Computer-based diagnostics and systematic analysis of knowledge. New York, NY: Springer.

Itoyama, K., Nitta, T., \& Fujiki, T. (2007). On the Relation between Semantic Network and Association Map for the Assessment of Class Work. In M. Iskander (Ed.), 
Innovations in E-learning, Instruction Technology, Assessment, and Engineering Education (pp. 199-204). New York, NY: Springer Verlag.

Izard, C. E. (1993). Four systems for emotion activation: Cognitive and noncognitive processes. Psychological Review, 100(1), 68-90.

Jensen, E. (2008). Brain-Based Learning: A new paradigm for learning (2nd ed.). Thousand Oaks, CA: Corwin Press.

Jonassen, D. H., Beissner, K., \& Yacci, M. (1993). Structural Knowledge: Techniques for representing, conveying, and acquiring structural knowledge. Hillsdale, NJ: LEA.

Jones, B. F., \& Idol, L. (Eds.) (1990). Dimensions of thinking and cognitive instruction. Hillsdale, NJ: Lawrence Associates Publishers.

Joughin, J. (Ed.) (2009). Assessment, learning and judgement in higher education. Dordrecht, Netherlands: Springer Verlag.

Khan, B. H. (2005). Managing e-learning: design, delivery, implementation and evaluation. Hershey, PA: Information Science Publishing.

Klopfer, E. (2008). Augmented learning: Research and design of mobile educational games. Cambridge, MA: MIT press.

Knowles, M. S., Holton III, E. F., \& Swanson, R. A. (1998). The adult learner: The definitive classic in adult education and human resource (5th ed.). Houston, TX: Gulf Pub. Co.

Lachman, R., Lachman, J. L., \& Butterfield, E. C. (1979). Cognitive Psychology and information processing: An introduction. Hillsdale, NJ: Erlbaum.

Lindsay, P. H., \& Norman, D. A. (1977). Human Information Processing: An introduction to Psychology. New York, NY: Academic Press.

Lopez, E. O., \& Theios, J. (1992). Semantic analyzer of schemata organization (SASO). Behavior Research Methods, Instruments, $\mathcal{E}$ Computers, 24(2), 277-285. doi:10.3758/BF03203508

Lopez, R. E. O., \& Theios, J. (1996). Single word schemata priming: a connectionist approach. In 69th Annual Meeting of the Midwestern Psychological Association, Chicago, IL.

Lopez, R. E. O., Morales, M. G. E., Hedlefs, A. M. I., \& Gonzalez, T. C. J. (2014). New empirical directions to evaluate online learning. International Journal of Advances in Psychology, 3(2), 40-47. doi:10.14355/ijap.2014.0302.03

Madaus, G. F., \& Stufflebeam, D. (2002). Program evaluation: A Historical Overview. In S. Daniel, M. George, \& K. Thomas (Eds.), Evaluation models: Viewpoints on educational and human services evaluation (pp. 3-18). New York, NY: Kluwer Academic Publishers.

Marzano, R. J. (1994). Lessons from the field about outcome-based performance assessments. Educational Leadership, 51(6), 44-50.

Marzano, R. J., Brandt, R. S., Huges, C., Jones, B. F., Presseisen, B. Z., Ranking, S. C., \& Suhor, G. (1988). Dimensions of thinking: A framework for curriculum and instruction. Alexandria, VA: The Association for Supervision and Curriculum Development ASCD.

Marzano, J., Brandt, R. S., Hughes, C. S., Jones, B. F., Presseisen, B. Z., Rankin, S. C., \& Suhor, C. (1991). Dimensions of thinking: A framework for curriculum and instruction. In A. L. Costa (Ed.), Developing minds: A resource book for teaching and 
thinking (pp. 89-93). Alexandria, VA: The Association for Supervision and Curriculum Development ASCD.

Marzano, R. J., \& Costa, A. L. (1998). Question: Do standardized tests measure general cognitive skills? Answer: No. Educational Leadership, 45(8), 66-71.

Marzano, R. J., \& Pickering, D. J. (1991). Dimensions of learning an integrative instructional framework. In A. L. Costa (Ed.), Developing minds: A resource book for teaching and thinking (pp. 94-99). Alexandria, VA: The Association for Supervision and Curriculum Development ASCD.

Marzano, R. J., Pickering, D. J., Arredondo, D. E., Blackburn, G. J., Brandt, R. S., \& Moffett, C. A. (1992). Dimensiones del aprendizaje: Manual del profesor. Alexandria, VA: The Association for Supervision and Curriculum Development ASCD.

Mayer, R. E. (1996). Learners as information processors: Legacies and limitations of educational psychology's second metaphor. Educational Psychologist, 31(3-4), 151161.

Morales-Martinez, G. E., \& Lopez-Ramirez, E. O. (2016). Cognitive responsive eassessment of constructive e-learning. Journal of e-Learning and Knowledge Society, 12(4), 39-49. doi:10.20368\%Fje-lks.v12i4.1187

Morales-Martinez, G. E., Lopez-Ramirez, E. O., \& Lopez-Gonzalez, A. E. (2015). New approaches to e-cognitive assessment of e-learning. International Journal for eLearning Security (IJeLS), 5(2), 449-453. doi:10.20533/ijels.2046.4568.2015.0057

Morales-Martinez, G. E., \& Santos-Alcantara, M. G. (2015). Alternative empirical directions to evaluate schemata organization and meaning. Advances in Social Sciences Research Journal, 2(9), 51-58. doi:10.14738/assrj.29.1412

Muldoon, N., \& Lee, C. (2007). Formative and summative assessment and the notion of constructive alignment. In F. Steve (Ed.), Enhancing teaching and learning through assessment (pp. 98-108). New York, NY: Springer Verlag.

Musch, J., \& Klauer, K. C. (Eds.) (2003). The psychology of evaluation: affective processes in cognition and emotion. Hillsdale, NJ: Lawrence Erlbaum Associates Publishers.

Nelson, T. H. (1982). Literary Machines. Sausalito, CA: Mindful Press.

Nichols, P., \& Sugrue, B. (1999). The lack of fidelity between cognitively complex constructs and conventional test development practice. Educational Measurement: Issues and Practice, 18(2), 18-29.

Nickerson, R. S., Perkins, D. N., \& Smith, E. E. (1985). The teaching of thinking. Hillsdale, NJ: Lawrence Erlbaum Associates Publishers.

Nickerson, R. S. (1987). Why teach thinking? In J. Boykoff Baron \& R. J. Sternberg (Eds.), Teaching thinking skills: Theory and practice (pp. 27-37). New York, NY: W. H. Freeman and Company.

Payne, C. R. (2009). Information technology and constructivism in higher education: Progressive learning frameworks. New York, NY: Information Science Reference Pub.

Perez, C. N., Hernandez, C. D., Bustillo, H. C., \& Figueroa, N. J. (2012). Model of natural semantic space for ontologies' construction. International Journal of Combinatorial Optimization Problems and Informatics, 3(2), 93-108.

Psaromiligkos, Y., Spyridakos, A., \& Retalis, S. (2014). Evaluation in e-learning. New York, NY: Nova Science Publisher, Inc. 
Power, M., \& Dalgleish, T. (2008). Cognition and Emotion: From Order to Disorder (2nd ed.). New York, NY: Psychology Press.

Rumelhart, D. E., Smolensky, P., McClelland, J. L., \& Hinton, G. E. (1986). Schemata and sequential thought processes. In J. L. McClelland, D. E. Rumelhart, \& The PDP Research Group (Eds.), Parallel distributed processing: Explorations in the microstructure of cognition, Vol. 2: Psychological and biological models (pp. 7-57). Cambridge, MA: MIT Press.

De Sánchez, M. (2004). Aprende a pensar. Solución de problemas. Mexico, Mexico: Ed. Trillas.

Sanders, W. L., \& Horn, S. P. (1995). Educational assessment reassessed: The usefulness of standardized and alternative measures of student achievement. Education policy analysis archives, 3(6), 1-15.

Seel, M. N. (2010). Essentials of computer-cased diagnostics of learning and cognition. In D. Ifenthaler, P. Pirnay-Dummer, \& N. M. Seel (Eds.), Computer-Based Diagnostics and Systematic Analysis of knowledge (pp. 3-14). New York, NY: Springer Verlag.

Sharon, Y., Tettega, M., \& Mcreery, M. P. (2015). Emotions, technology, and learning. New York, NY: Academic Press.

Shute, V. J., \& Becker, B. J. (2010). Prelude: Assessment for the 21st Century. In V. J. Shute \& B. J. Becker (Eds.), Innovative assessment for the 21st century (pp. 1-11). New York, NY: Springer.

Sternberg, R. J. (1985). Beyond IQ: A triarchic theory of human intelligence. Cambridge, UK: Cambridge University Press.

Stufflebeam, D. L., Madaus, G. F., \& Kellaghan, T. (2002). Evaluation models: Viewpoints on Educational and Human Services Evaluation (2nd ed.). New York, NY: Kluwer Academic Publishers.

Stufflebeam, D. L., \& Shinkfield, A. J. (1989). Evaluación sistemática: guía teórica y práctica. Barcelona, Spain: Paidós.

The Institute for Higher Education Policy (TIHEP). (1999). What's the. A review of contemporary research on the effectiveness of distance learning in higher education. Washington, DC: The Institute for Higher Education Policy. Retrieved from http://www.ihep.org/sites/default/files/uploads/docs/pubs/whatdifference. pdf

Tillema, H. H. (2009). Assessment for learning to teach: appraisal of practice teaching lessons by mentors, supervisors, and student teachers. Journal of Teacher Education, 60(2), 155-167.

Woolf, B. P., Aimeeur, E., Nkambou, R., \& Lajoie, S. (2008). Intelligent Tutoring Systems. 9th International Conference, ITS 2008 Montreal, Canada. 